\title{
Analysis of Dividend Policy and Its Impact on Shareholders Wealth Maximization in Nigerian Firms (A Study of Brewery Industry)
}

\author{
Cordelia Onyinyechi Omodero' ${ }^{1}$, Kalu Ogbonnaya Amah ${ }^{1}$ \\ ${ }^{1}$ Department of Accounting, Michael Okpara University of Agriculture, Umudike, P.M.B. 7267, Umuahia, Abia State, \\ Nigeria
}

Correspondence: Department of Accounting, Michael Okpara University of Agriculture, Umudike, P.M.B. 7267, Umuahia, Abia State, Nigeria.

Received: June 1, 2017

Accepted: July 13, $2017 \quad$ Available online: July 16, 2017

doi:10.11114/aef.v4i5.2542

URL: https://doi.org/10.11114/aef.v4i5.2542

\begin{abstract}
The study evaluated dividend policy and measured its impact on shareholders' wealth maximization in Nigerian firms (a study of brewery industry). A cross-survey research design was adopted and secondary data extracted from the published annual reports of the firms studied. The statistical tool used was a multi-regression analysis and t-test for hypotheses testing and data analysis with the aid of SPSS version 20. The result in Guinness Nigeria Plc., indicated the irrelevance of dividend policy. From the result, the DPS, EPS and NAPS which were the explanatory variables, had no positive impact on the market value per share (MPS) both collectively and individually. The result from Nigeria Breweries Plc., proved dividend policy is relevant to an extent to which earnings per share and net asset per share are positively affected. The F-ratio was 0.000 which shows a significant positive impact on the MPS. The earnings per share and net asset per share were also significant except the dividend per share which had no impact on the market value per share. The implication is that the growth in stock prices is not always a function of dividend payment.
\end{abstract}

Keywords: dividend policy, dividend per share, earnings per share, market price per share, net asset per share

\section{Introduction}

Dividend has been defined by the Institute of Chartered Accountants of India, as "a distribution to shareholder out of profits or reserves available for this purpose". According to Rustagi (2001), "the term dividend refers to that portion of profit (after tax) which is distributed among the owners/shareholders of the firm". Maheshwari (1999) defines dividend as the return the shareholders receive from the enterprise, which is a portion taken out of the profit, for their shareholdings. Therefore, dividend policy of a firm determines and influences a company's decision in its payments to the shareholders and the amount to be retained (Omodero, 2005). Business Jargons (2017) refers to dividend policy as a financial decision that is focused on the proportion of the firm's earnings to be paid out to the shareholders. That means, the company has to decide on the portion of the profit to be distributed to the shareholders as dividend or to be ploughed back into the business. History has proved that investors depend on dividend payment ratio in their decision to invest in companies. Thus, firms that pay high dividend are more attractive to investors, but from the firms' point of view, high dividend payment increases their financial burdens. High dividend payment companies reduce payment at a certain level to maintain the financial position of the firm (NainTarasarfarzRaja, 2014). This is the major difference between an investor and a speculator a speculator does not wants to take risk in response of abnormal return while an investor is more concerned with constitute performance of that assets in which he has invested his fund. This consistent performance of an asset (security) is dependent in the performance of the policies of the managers. The main responsibility of the financial manager is to maximize the shareholders wealth and it's very important for him to have good understanding of dividend and dividend policy because any good and bad decision about dividend can affect the wealth of shareholders (NainTarasarfarzRaja, 2014). Dividend policy and its effect on the share prices of companies has remained a controversial issue. Many researchers have argued that dividend policy impacts on shareholders' wealth (Enhardt, 2013; Ogolo, 2012, Azhagaiah \& Priya, 2008) as against the work of Miller and Modigliani (1963) which holds the view that dividend policy has minimal effect on the investment decision of an investor. This controversy has necessitated this study. The focus is on the impact of dividend policy on the maximization of shareholders wealth in the two (2) major brewery firms in Nigeria, namely: Nigerian Breweries PLC and Guiness Nigeria PLC. Brewery firms in Nigeria especially the Nigeria Breweries Plc and Guinness Nigeria Plc make use of Dividend policy in other to create 
resources from long term capital investment project or other anticipated further expenditure. The two brewery companies mentioned above are the leader of the highly capital intensive industry in Nigeria which largely automated their production lines.

\subsection{Objective of the Study}

The main objective of the research is Analysis of dividend policy as a strategic tool for shareholders wealth maximization in Nigeria (a study of brewery industry). The study also seeks to achieve the following specific objectives:

(1) To investigate the extent to which dividend per share affects share prices in Brewery industries.

(2) To examine the effect of earnings per share on share prices.

(3) To assess the impact of net asset per share on the market value per share.

\subsection{Research Questions}

To pursue to above objectives the following research question have been raised

(1) To what extent does dividend per share affect shareholders wealth (share price)?

(2) What effect does earnings per share have on shareholder wealth (share price)?

(3) To what extent does net asset per share influence market value per share?

\subsection{Research Hypothesis}

To achieve the objective of this study the following research hypotheses have been formulated

$\mathrm{HO}_{1} \quad$ Dividend per share does not significantly influence share price of the brewery industry.

$\mathrm{HO}_{2}$ Earnings per share does not have any effect on the share price of the brewery firms.

$\mathrm{H}_{3} \quad$ Net asset per share does not significantly affect the market value per share of brewery firms.

\section{Theoretical Review}

The theoretical review of this research is based on the conceptual definitions, various theories propounded by some leading authors and finally the empirical review which is the study other researcher have done on the same topic.

\subsection{Conceptual Definitions}

\subsubsection{Dividend}

Pandy (2001) defines dividend as that portion of a company's net earnings which the directors recommend to be distributed to shareholders in proportion to their shareholdings in the company. It is usually expressed as a percentage of nominal value of the company's ordinary share capital or as a fixed amount per share. Dividend is referred to as that part of the enterprise earnings that is given to shareholders as interest on their investment. It represents the return to investors who put their money at risk in the company. Firms pay dividend to reward existing shareholders and encourage others that are prospective shareholders to buy new issues of the common stock at high price.

\subsubsection{Dividend Policy}

Agundu (2000) defines dividend policy as "the decision relating to corporate earnings and pay-outs directed at maximizing shareholders return on investment"

Van Horne (2001) describes dividend policy as the division of earnings between shareholders and reinvestment for expansion in an enterprise. Retained earnings are a significant source of funds for financing corporate growth, but dividend constitutes the cash flows that accrue to shareholders. There exist two divergent schools of thought with regards to these, the dividend policy and the retained earning policy. Dividend Policy is a decision by the financial manager whether the firm should distribute all profit or retain them or to distribute a portion and retain the balance. Dividend policy is an important aspect of corporate finance.

\subsubsection{Determinants of Dividend Policy}

Chand (2017) identified the following determinants of dividend policy:

- Type of industry. A more unswerving dividend policy can be articulated by industries that have stable income flow than those that have irregular income flow.

- Age of corporation. Companies that have operated for a long time could have the opportunity of putting in place a straight forward dividend policy than the newly established firms which focus more on expansion.

- Extent of share distribution. A company with few number of shareholders can easily have a restricted dividend policy. That means, if it is necessary to suspend payment of dividend, the consent from shareholders 
are gotten easily. In a scenario where shareholders are numerous a widely scattered, co-operation is difficult to achieve where there is need for changes in the dividend policy.

- Need for additional capital. Dividend policy can also be influenced by the extent to which profits are required to be ploughed back into the firm for future expansion.

- Business cycles. A dividend policy is usually affected by inflation and recession. A discreet corporate management makes room for good reserve during a booming period to be able to overcome the challenge of inflation and recession.

- Changes in government policies. Government policies could sometimes restrict dividend declaration by companies in some industries. When such happens, the rate of dividend to be declared must be strictly based on the government policy in place at the moment.

- Trends of profits. A careful study of a company's profit trend and the general economic condition within those years will determine the appropriate dividend policy to be adopted. A conservative dividend policy is preferred if an unfavourable economic condition is suspected.

- Taxation policy. Taxation policies do have effect on dividends directly and indirectly. If the residual profits to be distributed to shareholders are reduced, it means dividend is directly affected. Dividends beyond a certain limit is also subject to tax.

- Future requirements. Firms need profits to expand their businesses, switch over to new technologies and for equipment replacement. It is therefore the duty of the management to strike a balance between dividend payment and business expansion.

- Cash balance. In a situation where a firm's working capital appears to be small, the dividend policy to be adopted must not be liberal. The dividend has to be in form of bonus shares issue to the members, instead of cash payment.

\subsubsection{Earnings Per Share (EPS)}

According to Ready Ration (2017), earnings per share is the portion of the company's distributable profit which is allocated to each outstanding equity share (common share). Alzomaia \& Al-khadhiri (2012), define earnings per share as the amount of earnings per each outstanding share of a company's stock, and calculated by dividing current net profit on total outstanding shares. However, earning per share "represents the portion of a company's earnings, net of taxes and preferred stock dividends, which is allocated to each share of common stock. The figure can be calculated simply by dividing net income earned in a given reporting period (usually quarterly or annually) by the total number of shares outstanding during the same term. Because the number of shares outstanding can fluctuate, a weighted average is typically used" (investing answers, 2017). The implication of earnings per share is that it can lead to growth in stock prices, and when they do, investors stand to benefit financially. If a company has high earnings per share, it means it has more money available to either plough back in the business or distribute to shareholders in the form of dividend payments. In either scenario, the investors are at advantage (Motley Fool, 2017).

\subsubsection{Shareholders Wealth Maximization}

Shareholders wealth maximization is a norm of corporate governance that encourages a firm's board of directors (the board) to implement all major decisions such as compensation policy, new investments dividend policy, strategic direction and corporate strategy with only the interests of shareholders in mind, shareholders wealth maximization should be the primary norm underlying governance of for profit corporations (Sharfman, 2012).

\subsubsection{Net Asset Per Share (NAPS)}

The net asset value per share is defined by Ready Ratio (2017) as "an expression for net asset value that indicates the value per share for a fund (exchange-traded, mutual, and closed-end) or a company. The basic calculation of assets per share is: net assets (total assets on the balance sheet less total liabilities) divided by the number of equity shares in issue. An increase in net assets per share by way of a share buyback, for instance, may bring about company's share growth (Reuters, 2017).

\subsection{Theoretical Review}

The study has been anchored on the dividend relevance and irrelevance theories as highlighted in the diagram below. 


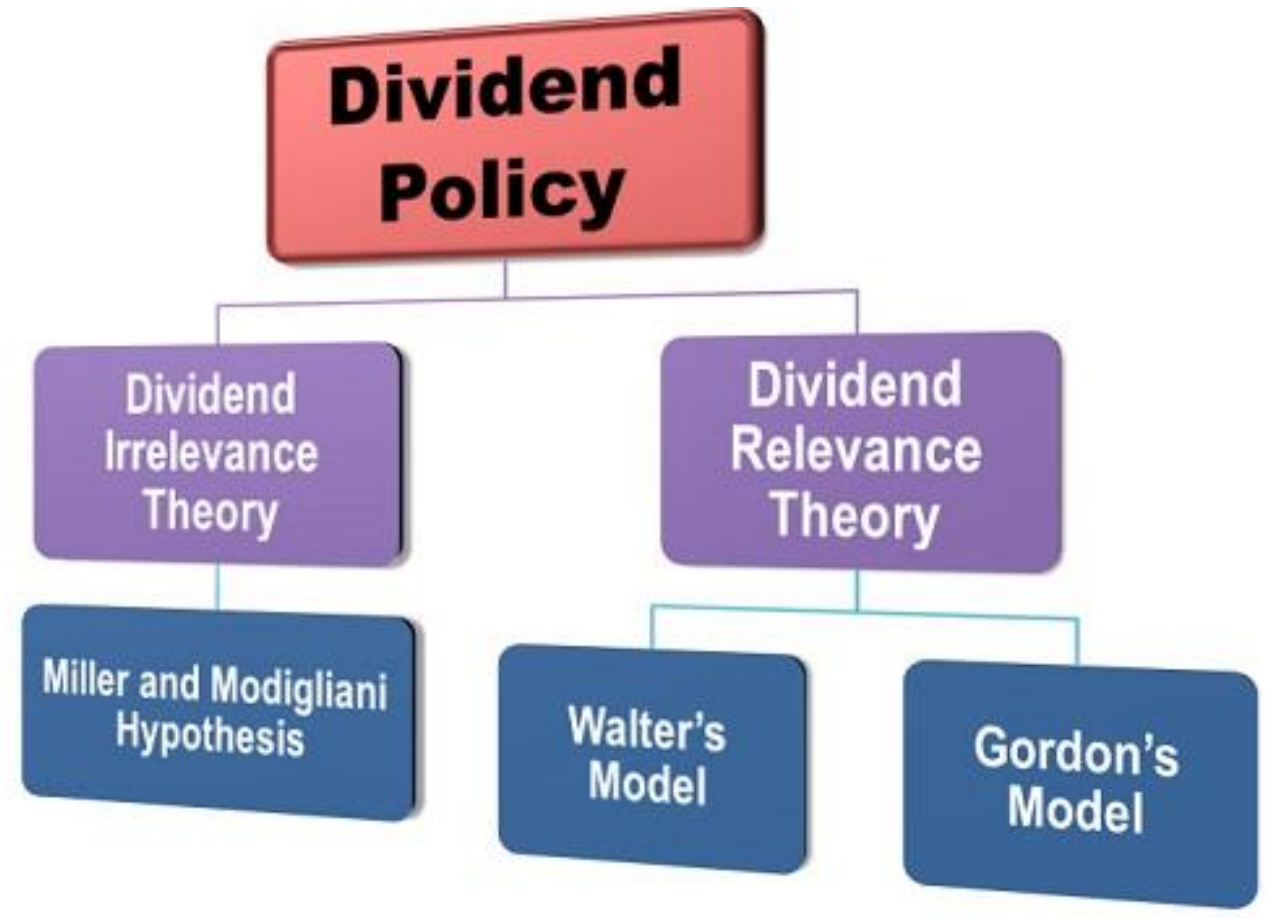

Source: Business Jargons. Retrieved on May 23, 2017.

\subsubsection{Dividend Irrelevance Theory}

This is a postulation that the dividend policy of a company should have minimal effect on the investment decisions made by an investor due to the fact that the payment or non-payment of a dividend will not necessarily impact on the net return to the investor. The assumption is that dividends not paid are reinvested by the company to generate more profit, thus higher stock values (WebFinance, 2017). The dividend irrelevance theory was propounded by Miller \& Modigliani (1963), according to them, dividend policy does not have effect on the share prices of firms because the value of the firm is dependent on its assets and revenue strength. Though Aswath (2000) in his study discovered that increase in dividend provides a good news while reduction in dividend discourages the investors. However, dividend irrelevance theory has been based on the following assumptions:

- There is an existence of perfect capital markets. That means, no taxes and floatation/ transaction costs.

- There is no risk of uncertainty.

- Free flow of information and that investors are rational.

- Investment policy of firms is not based on its dividend policy.

\subsubsection{Dividend Relevance Theory}

According to Walter (1963), share prices is a reflection of the present value of future dividends. Therefore, investment policy and dividend policy are inter related because if a proper dividend policy is formulated, the value of an enterprise is affected. This is further illustrated by the model below:

$$
\mathrm{P}=\frac{\mathrm{D}+\mathrm{r} / \mathrm{k}(\mathrm{E}-\mathrm{D})}{\mathrm{K}}
$$

Where, $\mathrm{P}=$ Market price of equity share; $\mathrm{D}=$ Dividend per share; $\mathrm{E}=$ Earnings per share; $(\mathrm{E}-\mathrm{D})=$ Retained earnings per share; $r=$ Internal rate of return on investment; $\mathrm{K}=$ Cost of capital.

Myron Gordon (1963) on the other hand holds the view that dividend policy of a firm forms the basis of establishing share value. The model below is a proof of Gordon's view:

$$
\mathrm{P}_{0}=\underline{\mathrm{E}}_{1}(1-\mathrm{b})
$$

Where, $\mathrm{P}_{0}=$ Price per share at the end of year $0 ; \mathrm{E}_{1}=$ Earnings per share at the end of year $1 ;(1-\mathrm{b})=$ Fraction of earnings the firm distributes by way of dividends; $b=$ Fraction of earnings the firm ploughs back; $k=$ Rate of return required by shareholders; $r$ =Rate of return earned on investments made by the firm; br =growth rate of dividend and earnings. 


\subsection{Empirical Review}

Ogolo (2012), carried out a research to examine the impact of dividend policy on share prices with a sample of 61 companies quoted on the Nairobi Stock Exchange. The study covered a period of 10 years ranging from 2003-2012. It was revealed that a significant positive relationship exists between market price per share and the two main dividend policy tools-earnings per share and dividend per share. The researcher concluded that dividend policy has a strong influence on share prices.

Munyua (2012), examined the effect of dividend policy on stock prices for firms, listed at the Nairobi Securities Exchange. The study adopted a descriptive research design using a secondary data extracted from 61 quoted firms on the Nairobi Securities Exchange between the periods of 2004-2013. The statistical tool employed was regression model and it was discovered that a strong positive relationship exists between dividend per share and the share prices. It was also noted that share prices are affected by the paid out dividend per share. The study concluded that share prices are strongly affected by dividends.

AL-Shubiri (2010), investigated 14 Jordanian Commercial banks listed on the Amman Stock Exchange with the focus on determining the stock price movements. The study spanned from the period of 2005-2008. The research revealed that market price per share and the net asset per share and have a strong positive significant relationship.

Anike (2014) studied the impact of dividend policy and earnings on stock prices of Nigerian Banks. Ex-post-facto was the research design adopted with the use of secondary data extracted from annual reports of banks spanning from 2006-2010. The statistical tool used was the ordinary least square regression model. The result indicates that earnings yield has a significant negative impact on stock prices of banks in Nigeria, while dividend per share has a non-significant negative impact on share prices of banks. The shows that dividend policy does not actually influence stock prices but the size of the bank. In other words, the study has in a way confirmed the irrelevance theory of Miller and Modigliani (1963). On the contrast, Abiola (2014) argued that dividend policy is a strategic tool for growth in the banking industry since its dividend payout impacts on the wealth maximization of the shareholders.

\subsection{Gap in Literature}

The divergence views on this topic has necessitated this study. The researchers therefore deem it wise to explore the true position of the effect of dividend policy on companies using a wide range of existing data from 2003-2016. With these number of years including the immediate past year, the research will be able to reveal the extent to which dividend policy is relevant or irrelevant to stock value of firms. The studies above did not span beyond 10 years period. That is why this current research has been taken beyond ten (10) years to be able to draw a suitable conclusion on the issue at hand.

\section{Research Method}

\subsection{Research Design}

The research design taken on in this study is a cross sectional survey which has to do with a assessment of already existing secondary data.

\subsection{Methods of Data Collection and Technique of Analysis}

Time Series Annual data was employed ranging from 2003 - 2016 with a sample size of 2 brewery firms in Nigeria. The research instruments used in collection of data for this study were mainly secondary data from the NSE Website and Annual reports published by the companies selected.

Descriptive and inferential statistics were used to analyze the data for this study. Also multiple regression and t-test statistical tools were used to test the hypothesis formulated in this study.

\subsection{Model Specification}

This study used the econometric technique of Ordinary Least Square (OLS) in form of Multiple Linear Regressions to the relative regression coefficients. The regression model was estimated through the use of Statistical Package for Social Sciences (SPSS).

The mathematical model for the study is as follows:

$$
\text { MPS }=\mathrm{f}(\mathrm{DPS}, \text { EPS, NAPS })
$$

Where,

MPS =Market price per share, DPS=Dividend per share, EPS=Earnings per share, NAPS=Net Asset per share

Mathematical Specification:

$$
\mathrm{Y}_{\mathrm{i}}=\mathrm{b}_{0}+\mathrm{b}_{1} \mathrm{X}_{1}+\mathrm{b}_{2} \mathrm{X}_{2}+\mathrm{b}_{3} \mathrm{X}_{3}+\mathrm{e}
$$

Where, 
$\mathrm{Y}_{1}=$ Market price per share, $\mathrm{X}_{1}=$ Dividend per share, $\mathrm{X}_{2}=$ Earnings per share, $\mathrm{X}_{3}=$ Net Asset per share, $\mathrm{b}_{0}=$ The parameter which represents the intercept, $b_{1}, b_{2}, b_{3}=$ The regression parameters used in determining the significance of the impact of each of the independent or explanatory variables $\mathrm{X}_{1}, \mathrm{X}_{2}, \mathrm{X}_{3}$ on dependent variable, $\mathrm{Y}_{1}$. $\mathrm{e}=$ Random disturbance term.

\section{Results and Discussion}

\section{GUINNESS NIG PLC}

Result on the impact of DPS, EPS \& NAPS on MPS.

\begin{tabular}{ll}
\hline $\mathrm{R}$ & 0.702 \\
\hline $\mathrm{R}^{2}$ & 0.492 \\
Adjusted $\mathrm{R}^{2}$ & 0.340 \\
F-ratio & 3.230 \\
*** Significant at & 0.069 \\
T-test: DPS & 1.479 \\
EPS & 0.589 \\
NAPS & 1.824 \\
$* * *$ Significant at: DPS & 0.17 \\
EPS & 0.57 \\
NAPS & 0.10 \\
\hline
\end{tabular}

Source: SPSS Version 20 Result

NIGERIA BREWERIES PLC

Result on the impact of DPS, EPS \& NAPS on MPS.

\begin{tabular}{lc}
\hline $\mathrm{R}$ & 0.945 \\
\hline $\mathrm{R}^{2}$ & 0.893 \\
Adjusted $\mathrm{R}^{2}$ & 0.860 \\
F-ratio & 27.711 \\
$* * *$ Significant at & 0.000 \\
T-test: DPS & -1.526 \\
EPS & 2.590 \\
NAPS & 4.389 \\
$* * *$ Significant at: DPS & 0.16 \\
EPS & 0.03 \\
NAPS & 0.00 \\
\hline
\end{tabular}

Source: SPSS Version 20 Output

\subsection{Test of Hypotheses}

The hypotheses formulated earlier state that market value per share (MPS) is not influenced by dividend per share (DPS), earning per share (EPS) and net asset per share (NAPS). In other words, the independent variable do not affect the dependent variable. From the result shown above for Guinness Nigeria Plc., the F-ratio 0.069 means the collective result is not significant since it is higher than the acceptable level of significance at $0.05(5 \%)$. The individual results also reveal that DPS, EPS and NAPS are significant at $0.17,0.57$, and 0.10 respectively. Thus, none is significant since they are all above 0.05. In the same vain, the collective result (F-ratio) of Nigeria Breweries PLC indicates an acceptable level of significance of 0.000 which is far lower than 0.05 . The individual results reveal that DPS, EPS and NAPS are significant at $0.16,0.03$ and 0.00 respectively. That is, EPS and NAPS are below the set standard (0.05) while DPS is above it.

\subsection{Discussion and Findings}

From the results that have emerged, it is obvious that dividend policy does not have any impact on the share prices of Guinness Nigeria Plc. The dividend per share, earnings per share and net asset per share reveal no impact on share values. This discovery has proved the dividend policy irrelevance theory of Miller and Modigliani (1963) which says that share values are not affected by increase or decrease in dividend payment, but rather investors' act based on the revenue strength of a firm. The study of Anike (2014), has also been supported by this result. In that study, the results showed that the stock prices of Nigerian Banks are not influenced by the dividend payout, because the dividend per share had no significant impact on the share prices. The result of Nigeria Breweries Plc., proves that dividend policy is relevant to the extent that it affects the earnings per share and net asset per share. That means the aspect of the policy that improves shareholders earnings and the net worth of the firm will positively impact on the share prices not necessarily the dividend to be paid out. 


\section{Conclusion and Recommendation}

The study is a comprehensive evaluation and analysis of the impact of dividend policy on share values of firms using the 2 giant brewery companies in Nigeria as a case study. All that anyone can deduce is that dividend policy is both relevant and irrelevant depending on the firm and the management skill of the financial manager and the board of directors. During a depressed economy, dividend declaration could be reduced to be able to have enough fund to plough back into the business to avoid collapse. The asset base and revenue strength of every firm are stronger attractions to investors. Investors these days make informed investment decisions which dividend payment is less the focus. If the management is skilled enough to put the right priorities in place, share values will ever appreciate.

\section{APPENDIX 1}

\begin{tabular}{clllc}
\hline GUINNESS & & & & EPS \\
\hline YEAR & MPS & DPS & K & K \\
& K & K & 931 & 2,937 \\
$\mathbf{2 0 0 3}$ & 7,000 & 475 & 671 & 2,319 \\
$\mathbf{2 0 0 4}$ & 16,100 & 525 & 412 & 1,545 \\
$\mathbf{2 0 0 5}$ & 8,700 & 300 & 631 & 1,775 \\
$\mathbf{2 0 0 6}$ & 10,890 & 400 & 784 & 2,321 \\
$\mathbf{2 0 0 7}$ & 12,655 & 346 & 804 & 2,499 \\
$\mathbf{2 0 0 8}$ & 12,400 & 450 & 918 & 2,137 \\
$\mathbf{2 0 0 9}$ & 12,900 & 1,280 & 931 & 2,319 \\
$\mathbf{2 0 1 0}$ & 15,851 & 750 & 1,216 & 2,731 \\
$\mathbf{2 0 1 1}$ & 24,500 & 825 & 995 & 2,618 \\
$\mathbf{2 0 1 2}$ & 25,000 & 1,000 & 793 & 3,057 \\
$\mathbf{2 0 1 3}$ & 23,800 & 800 & 636 & 2,992 \\
$\mathbf{2 0 1 4}$ & 20,000 & 700 & 518 & 3,210 \\
$\mathbf{2 0 1 5}$ & 16,281 & 320 & -134 & 2,767 \\
$\mathbf{2 0 1 6}$ & 10,925 & 320 & Rep \\
\hline
\end{tabular}

Source: Research Data 2017 Extracted from the Published Annual Reports of Guinness Nigeria PLC

\section{APPENDIX 11}

\begin{tabular}{lllll}
\hline NB PLC & \multicolumn{1}{c}{} & \\
\hline YEAR & MPS & DPS & EPS & NAPS \\
$\mathbf{2 0 0 3}$ & K & K & K & K \\
$\mathbf{2 0 0 4}$ & 6,320 & 210 & 194 & 379 \\
$\mathbf{2 0 0 5}$ & 4,080 & 55 & 77 & 479 \\
$\mathbf{2 0 0 6}$ & 3,880 & 65 & 109 & 571 \\
$\mathbf{2 0 0 7}$ & 3,725 & 120 & 144 & 426 \\
$\mathbf{2 0 0 8}$ & 4,900 & 159 & 250 & 616 \\
$\mathbf{2 0 0 9}$ & 4,085 & 485 & 340 & 663 \\
$\mathbf{2 0 1 0}$ & 5,302 & 180 & 369 & 1,035 \\
$\mathbf{2 0 1 1}$ & 7,710 & 354 & 401 & 978 \\
$\mathbf{2 0 1 2}$ & 9,442 & 125 & 508 & 1,236 \\
$\mathbf{2 0 1 3}$ & 14,700 & 300 & 503 & 1,486 \\
$\mathbf{2 0 1 4}$ & 16,790 & 300 & 546 & 2,153 \\
$\mathbf{2 0 1 5}$ & 16,530 & 575 & 562 & 2,172 \\
$\mathbf{2 0 1 6}$ & 13,600 & 470 & 482 & 2,091 \\
\hline
\end{tabular}

Source: Research Data 2017 Extracted The Published Annual Reports Of Nb Plc.

\section{References}

Abiola, J. O. (2014). Measuring and analyzing the effects of dividend policy in banking Profits and growth. Journal of Policy and Development Studies, 9(1), 167-178. https://doi.org/10.12816/0011190

Agundu, P. U. (2000). Finance Finnese. $1^{\text {st }}$ Edition. Outreach publications. Port Harcourt.

AL-Shubiri, F. N. (2010). Analysis of the determinants of market stock price movements: An Empirical study of Jordanian Commercial banks. International Journal of Business and Management, 5(10), 137-147. https://doi.org/10.5539/ijbm.v5n10p137

Alzomaia, T. S. F., \& Al-khadhiri, A. (2012). Determination of dividend policy. The evidence From Saudi Arabia. College of Business Administration Saudi Riyadh.

Anike, E. A. (2014). The impact of dividend policy and earnings on stock prices of Nigeria Banks. Published MSc project. University of Nigeria, Nsukka. 
Aswath, D. (2000). The determinants of dividend policy, corporate finance: theory and Practice; John Wiley \& Sons, Inc., 544-570.

Azhagaiah, R., \& Priya, N. S. (2008). Effect of dividend policy on shareholders' wealth. International Research Journal of Finance and Economics, 20, 189-187.

Busiiness Jargons Finance (2017). Dividend Policy. http://businessjargons.com/dividend- Policy.html. Retrieved: May 23, 2017.

Chand, S. (2017). 10 most important determinants of dividend policy/financial management. http://www.yourarticlelibrary.com/financial-management/10-most-important-Determinants-of-dividend-policy-fina ncial-management/26237/. Retrieved May 23, 2017.

Enhardt, M. (2013). Corporate Finance: A focused approach. London, UK: Cengage Learning.

Gordon, M. J. (1963). Optimum investing and financing policy. Journal of Finance, 18(2), 264-272, May 1963.

Institute of Chartered Accountants of India (ICAI). Guidance Note on terms used in Financial Statements.

Investing Answer (2017). Earnings per share (EPS). http://www.investinganswers.com/financial-dictionary/financial-statement-Analysis/earnings-share-eps-1003. Retrieved May 28, 2017.

Maheshwari, S. N. (1999). Elements of Financial Management, Sultan Chand and Sons, 71.

Miller, M. H., \& Modigliani, F. (1961). Dividend Policy, growth, and the valuation of shares. The Journal of Business, 34(4), 411-433. https://doi.org/10.1086/294442

Motley Fool (2017). What is earning per share. https://www.fool.com/knowledge-center/earnings-per-share.aspx. Retrieved May 28, 2017.

Munyua, P. N. (2012). Effect of dividend policy on stock prices for firms listed at the Nairobi Securities Exchange. Published MBA project, University of Nairobi, Nairobi, Kenya.

NainTarasarfarzRaja, A. (2014). Impact of dividend policy on shareholder wealth. IOSR Journal of business and management (IOSR-JBM). 16(1), 24-33. https://doi.org/10.9790/487X-16152433

Ogolo, D. A. (2012). The effect of dividend policy on share prices of multinational and local Companies listed at the Nairobi Securities Exchange. Unpublished MBA project, University of Nairobi, Nairobi, Kenya.

Omodero, C. O. (2005). The impact of Corporate Dividend Policy on Corporate Financing. (A Survey of selected quoted firms in the manufacturing industry). Unpublished BSc project, University of Science and Technology, Rivers State, Nigeria.

Pandy, I. (2001). Corporate dividend policy and behavior the Malaysian experience, working Paper, no. 2001-11-01.

Ready Ratio (2017). Earnings per share (EPS). https://www.readyratios.com/reference/Accounting/earnings-per-share-eps.html. Retrieved May 28, 2017.

Rustagi, R. P. (2001). Financial Management. Galgotia Publishing Company, 806.

Van Horne, C. J. (2001). Financial Management (11 ${ }^{\text {th }}$ Ed.), New Delhi, Prentice Hall.

Walter, J. E. (1963). Dividend Policy: its influence on the value of the enterprise. The Journal of Finance, 18(2), 280-291, May 1963. https://doi.org/10.1111/j.1540-6261.1963.tb00724.x

\section{Copyrights}

Copyright for this article is retained by the author(s), with first publication rights granted to the journal.

This is an open-access article distributed under the terms and conditions of the Creative Commons Attribution license which permits unrestricted use, distribution, and reproduction in any medium, provided the original work is properly cited. 